\title{
PENGARUH KEMAMPUAN INDIVIDU DAN LINGKUNGAN KERJA TERHADAP SEMANGAT KERJA MELALUI KEPUASAN KERJA PEGAWAI PADA KANTOR BAWASLU KABUPATEN BARRU
}

\author{
Marsuki, Saban Echdar, Maryadi \\ email : marsuki.umar@gmail.com, sabanechdar@gmail.com, ahmadmaryadi@gmail.com \\ STIE NOBEL INDONESIA MAKASSAR
}

\begin{abstract}
ABSTRAK
Tujuan dari penelitian ini adalah Untuk menganalisis pengaruh langsung maupun tidak langsung antara kemampuan individu dan lingkungan kerja terhadap semangat kerja melalui kepuasan kerja pegawai pada Kantor Bawaslu Kabupaten Barru.

Dalam penelitian ini peneliti menggunakan jenis penelitian deskriptif dengan pendekatan kuantitatif. Populasi dalam penelitian ini adalah seluruh Pegawai di Kantor Bawaslu Kabupaten Barru sebanyak 101 orang, sehingga teknik sampel yang digunakan yaitu dengan sampel jenuh. Pengujian hipotesis dilakukan dengan menggunakan teknik analisis jalur dan uji sobel.

Hasil penelitian ini menunjukkan bahwa: Kemampuan individu dan lingkungan kerja secara langsung berpengaruh positif dan signifikan terhadap kepuasan kerja dan semangat kerja pegawai pada kantor Bawaslu Kabupaten Barru. Demikian halnya pengaruh tidak langsung dari Lingkungan kerja juga berpengaruh positif dan signifikan terhadap semangat melalui kepuasan kerja pegawai pada kantor Bawaslu Kabupaten Barru. Sedangkan Kemampuan individu secara tidak langsung berpengaruh positif namun tidak signifikan terhadap semangat melalui kepuasan kerja pegawai pada kantor Bawaslu Kabupaten Barru.
\end{abstract}

Kata Kunci : Kemampuan Individu, Lingkungan Kerja, Kepuasan Kerja, Semangat Kerja.

\section{ABSTRACT}

The purpose of this study was to analyze the direct and indirect effects between individual abilities and work environment on work morale through employee job satisfaction at the Barru District Bawaslu Office.

In this study, researchers used a type of descriptive research with a quantitative approach. The population in this study were all employees in the Barru Regency Government Office as many as 101 people, so the sample technique used was saturated samples. Hypothesis testing is done using path analysis techniques and the sobel test.

The results of this study indicate that: Individual ability and work environment directly have a positive and significant effect on job satisfaction and employee morale at the Barrulu Bawaslu office. Likewise the indirect effect of the work environment also has a positive and significant effect on morale through employee job satisfaction in the Bawaslu office of Barru Regency. While the individual's ability indirectly has a positive but not significant effect on morale through employee job satisfaction at the Barru Regency Bawaslu office.

Keywords: Individual Ability, Work Environment, Job Satisfaction, Work Morale.

\section{PENDAHULUAN \\ Latar Belakang}


Salah satu yang berperan penting dalam suatu organisasi adalah aspek sumber daya manusia (SDM), karena SDM yang mampu merencanakan, melaksanakan dan mengendalikan setiap aktivitas dalam organisasi demi pencapaian tujuan organisasi. Dengan demikian, organisasi perlu untuk senantiasa memberikan perhatian kepada sumber daya manusia yang dimiliki secara serius dibandingkan dengan sumber daya yang lainnya, dikarenakan SDM memiliki kemampuan pikiran, perasaan dan perilaku yang akan memberikan dampat positif dalam mempengaruhi pencapaian tujuan organisasi.

Penelitian ini dilakukan di kantor Bawaslu Kabupaten Barru, yang mana salah satu tujuan yang diharapkan oleh Bawaslu Kabupaten Barru adalah meningkatkan kualitas kinerja penanganan pelanggaran pemilu secara profesional. Pencapaian tujuan ini perlu didukung oleh adanya kemampuan individu dan lingkungan kerja terhadap semangat kerja melalui kepuasan kerja pegawai, sehingga Bawaslu mampu mewujudkan dirinya sebagai lembaga pengawal terpercaya dalam Penyelenggaraan Pemilu Demokratis, Bermartabat, dan Berkualitas.

Salah satu yang menarik adalah, adanya fenomena yang peneliti temukan di Kantor Bawaslu Kabupaten Barru misalnya dalam hal kemampuan individu pegawai, yakni masih rendahnya kemampuan pegawai dalam memahami Tupoksi masingmasing, sehingga berpengaruh semangat dalam bekerja. Kemudian, pegawai juga cenderung masih lama dalam menyelesaikan pekerjaan yang menjadi keluhan pimpinan maupun masyarakat. Disamping itu, dalam hal kondisi lingkungan kerja, adanya fenomena di Kantor Bawaslu Kabupaten Barru ditemukan dukungan akan sarana dan prasarana yang masih cenderung terbatas, misalnya unit komputer untuk menunjang pekerjaan pegawai, sehingga ada kecenderungan pegawai bermalas-malasan untuk bekerja karena harus bergantian dalam menggunakan komputer. Demikian halnya dengan kondisi dari koneksi jaringan internet yang lambat loading, penataan ruang kerja yang kurang baik, maupun ruang kerja yang sempit, sehingga situasi ini cenderung menghambat pekerjaan pegawai dan mengarah kepada kurang bersemangatnya pegawai dalam bekerja. Salah satu ciri dari kurang bersemangatnya pegawai dalam bekerja ditunjukkan dari tingkat absensi pegawai yang cenderung menurun dengan berbagai alasan yang kurang jelas.

Sejalan dengan uraian tersebut diatas, maka peneliti tertarik melakukan penelitian terkait dengan semangat kerja pegawai di Kantor Bawaslu Kabupaten Barru, dimana peneliti memandang perlu mengkaji lebih lanjut apakah faktor kemampuan individu dan lingkungan kerja yang menurun akan berdampak kepada semakin menurunnya semangat kerja pegawai, serta adanya ketidakpuasan sebagai variabel intervening juga akan semakin mempengaruhi semangat kerja pegawai atau tidak. Olehnya itu, judul dari penelitian ini adalah "Pengaruh Kemampuan Individu dan Lingkungan Kerja Terhadap Semangat Kerja Melalui Kepuasan Kerja Pegawai Pada Kantor Bawaslu Kabupaten Barru”.

Dalam penelitian ini dapat diuraikan rumusan masalah sebagai berikut : 1). Apakah kemampuan individu berpengaruh terhadap kepuasan kerja pegawai pada Kantor Bawaslu Kabupaten Barru?. 2). Apakah lingkungan kerja berpengaruh terhadap kepuasan kerja pegawai pada Kantor Bawaslu Kabupaten Barru?. 3). Apakah kemampuan individu berpengaruh terhadap semangat kerja pegawai pada Kantor Bawaslu Kabupaten Barru?. 4). Apakah lingkungan kerja berpengaruh terhadap semangat kerja pegawai pada Kantor Bawaslu Kabupaten Barru?. 5). Apakah kepuasan 
kerja berpengaruh terhadap semangat kerja pegawai pada Kantor Bawaslu Kabupaten Barru?. 6). Apakah kemampuan individu berpengaruh terhadap semangat melalui kepuasan kerja pegawai pada Kantor Bawaslu Kabupaten Barru?. 7). Apakah lingkungan kerja berpengaruh terhadap semangatmelalui kepuasan kerja pegawai pada Kantor Bawaslu Kabupaten Barru?

Berdasarkan rumusan masalah di atas, maka tujuan dari penelitian ini dapat diuraikan sebagai berikut: 1). Untuk menganalisis pengaruh kemampuan individu terhadap kepuasan kerja pegawai pada Kantor Bawaslu Kabupaten Barru. 2). Untuk menganalisis pengaruh lingkungan kerja terhadap kepuasan kerja pegawai pada Kantor Bawaslu Kabupaten Barru. 3). Untuk menganalisis pengaruh kemampuan individu terhadap semangat kerja pegawai pada Kantor Bawaslu Kabupaten Barru. 4). Untuk menganalisis pengaruh lingkungan kerja terhadap semangat kerja pegawai pada Kantor Bawaslu Kabupaten Barru. 5). Untuk menganalisis pengaruh kepuasan kerja terhadap semangat kerja pegawai pada Kantor Bawaslu Kabupaten Barru. 6). Untuk menganalisis pengaruh kemampuan individu terhadap semangat melalui kepuasan kerja pegawai pada Kantor Bawaslu Kabupaten Barru. 7). Untuk menganalisis pengaruh lingkungan kerja terhadap semangat melalui kepuasan kerja pegawai pada Kantor Bawaslu Kabupaten Barru.

Semangat kerja yang tinggi dikalangan pegawai ini akan menyebabkan kesenangan yang tinggi pula dalam melaksanakan setiap pekerjaan. Dalam hubungan dengan semangat kerja, maka suatu organisasi diharapkan mampu untuk meningkatkan semangat kerja pegawai. Nurbudiyani (2016) mengemukakan bahwa "apabila para pegawai terlihat senang, optimis, ramah maka mereka dikatakan mempunyai semangat yang tinggi/baik, sebaliknya apabila mereka nampak tidak puas, lekas marah, sering sakit, suka membantah, gelisah, pesimis maka reaksi-reaksi ini menunjukkan adanya semangat yang rendah/tidak baik. Dalam hal ini, pegawai yang memiliki semangat kerja yang rendah akan cenderung menimbulkan berbagai permasalahan seperti malas, kurang disiplin, cepat merasa bosan dalam bekerja dan sebagainya. Maka dapat dikatakan bahwa semangat kerja adalah kemauan pegawai untuk melakukan pekerjaan dengan giat dan antusias sehingga pekerjaan dapat terselesaikan lebih cepat dan lebih baik."

Untuk meningkatkan semangat kerja maka kepuasan kerja merupakan salah satu faktor penentu. Dalam Discrepancy theoryyang dicetuskan oleh Porter dalam As'ad (2001)bahwa "Discrepancy theorylebih mengukur kepuasan kerja seseorang dengan menghitung selisih antara apa yang seharusnya dengan kenyataan yang dirasakan (difference between how much of something there should be and how much there is now). Apabila yang didapat ternyata lebih besar dari pada yang diinginkan, maka akan menjadi lebih puas lagi, walaupun terhadap discrepancy yang positif. Sebaliknya makin jauh kenyataan yang dirasakan itu dibuat standar minimum sehingga menjadi negative discrepancy, maka makin besar pula ketidakpuasan seseorang terhadap pekerjaan. Kepuasan atau ketidakpuasan yang dirasakan oleh individu merupakan hasil dari suatu perbandingan yang dilakukan oleh dirinya sendiri terhadap berbagai macam hal yang mudah diperolehnya dari pekerjaan dan menjadi harapannya.

\section{METODE PENELITIAN}

Dalam penelitian ini peneliti menggunakan jenis penelitian deskriptif dengan pendekatan kuantitatif. "Metode Kuantitatif sering juga disebut metode tradisional, positivistic, ilmiah (Scientific) dan atau metode discovery. Metode 
kuantitatif dinamakan metode tradisional, karena metode ini sudah cukup lama digunakan sehingga mentradisi sebagai metode untuk penelitian (Echdar, 2017)." Disamping itu, penelitian ini tergolong Penelitian asosiatif karena merupakan penelitian yang bertujuan untuk mengetahui hubungan antara dua variabel atau lebih yakni Pengaruh kemampuan individu dan lingkungan kerja terhadap semangat kerja melalui kepuasan kerja pegawai di Kantor Bawaslu Kabupaten Barru. Lokasi Penelitian dilaksanakan pada Bawaslu Kabupaten Barru pada bulan Februari 2020.

Sampel dalam penelitian ini adalah seluruh Pegawai di Kantor Bawaslu Kabupaten Barru sebanyak 101 orang. Dikarenakan jumlah populasi yang relatif kecil, sehingga sampel yang digunakan yaitu dengan teknik sampling jenuh, yaitu keseluruhan populasi dijadikan sebagai sampel. Dengan demikian, maka sampel yang digunakan yaitu sebanyak 101 orang responden.

Teknik pengumpulan data yang digunakan dalam pengumpulan data adalah dengan menggunakan kuesioner. Kuesioner adalah daftar pertanyaan maupun pernyataan yang diajukan peneliti ke pada responden untuk dijawab secara sistematis guna memperoleh data sehingga dihasilkan data berupa respon atau tanggapan dari responden tersebut yang kemudian data ini yang akan diolah oleh peneliti.

Pernyataan-pernyataan dalam angket tertutup dibuat dengan menggunakan skala 1-5 untuk mendapatkan data yang bersifat interval dan diberi nilai atau skor, Dalam pengukurannya, setiap responden diminta pendapatnya mengenai suatu pernyataan, dengan skala penilaian dari 1 (satu) sampai dengan 5 (lima). Tanggapan positif atau sangat setuju maksimal diberi nilai paling besar 5 dan tanggapan negatif atau sangat tidak setuju minimal diberi nilai paling kecil 1.

\section{HASIL DAN PEMBAHASAN}

Hasil

\section{Uji Validitas dan Reabilitas}

Berdasarkan Uji Validitas dapat diketahui nilai $\mathrm{r}$ hitung (Corrected Item-Total Correlation) dalam semua variabel di atas 0,30 , sehingga sudah memenuhi syarat valid. Berdasarkan Uji Reabilitas, dapat diketahui nilai cronbach's alpha, yakni semua variabel yang diteliti tersebut nilainya lebih besar dari 0,60 , sehingga sudah memenuhi syarat suatu instrumen dikatakan Reliabel

\section{Analisis Jalur dan Pengujian Hipotesis Persamaan Analisis Jalur}

Tabel

Hasil Uji Path Analysis 1

\begin{tabular}{|c|c|c|c|c|c|c|}
\hline \multicolumn{7}{|c|}{ Coefficients $^{\mathrm{a}}$} \\
\hline \multirow{2}{*}{\multicolumn{2}{|c|}{ Model }} & \multicolumn{2}{|c|}{ Unstandardized Coefficients } & \multirow{2}{*}{$\begin{array}{c}\text { Standardized } \\
\text { Coefficients }\end{array}$} & \multirow[b]{2}{*}{$\mathrm{t}$} & \multirow[b]{2}{*}{ Sig. } \\
\hline & & $\mathrm{B}$ & Std. Error & & & \\
\hline 1 & (Constant) & .433 & .412 & & 1.051 & .296 \\
\hline & Kemampuan Individu & .234 & .113 & .170 & 2.079 & .040 \\
\hline & Lingkungan Kerja & .630 & .083 & .619 & 7.573 & .000 \\
\hline
\end{tabular}

a. Dependent Variable: Kepuasan Kerja 


\section{Sumber: Hasil Olah Data SPSS, 2020}

Berdasarkan tabel, maka dapat dinotasikan persamaan dari jalur pertama yaitu:

$$
Y_{1}=0,170 X_{1}+0,619 X_{2}+e_{1}
$$

1. Nilai koefisien jalur kemampuan individu $\left(\mathrm{X}_{1}\right)$ terhadap kepuasan kerja sebesar 0,170 . Artinya apabila kemampuan individu $\left(\mathrm{X}_{1}\right)$ naik 1 (satu) satuan dan variabel lainnya tetap, maka kepuasan kerja akan meningkat sebesar 0,170. Adapun nilai signifikansi sebesar 0,040 yang berarti kemampuan individu berpengaruh signifikan terhadap kepuasan kerja karena nilai sig. $<0,05$.

2. Nilai koefisien jalur lingkungan kerja (X2) terhadap kepuasan kerja sebesar 0,619.Artinya apabila lingkungan kerja (X2) naik 1 (satu) satuan dan variabel lainnya tetap, maka kepuasan kerja akan meningkat sebesar 0,619. Adapun nilai signifikansi sebesar 0,000 yang berarti lingkungan kerja berpengaruh signifikan terhadap kepuasan kerja karena nilai sig. $<0,05$.

\section{Tabel}

Hasil Uji Path Analysis 2

\begin{tabular}{|c|c|c|c|c|c|c|}
\hline \multicolumn{7}{|c|}{ Coefficients $^{\mathrm{a}}$} \\
\hline \multirow{2}{*}{\multicolumn{2}{|c|}{ Model }} & \multicolumn{2}{|c|}{ Unstandardized Coefficients } & \multirow{2}{*}{$\frac{\begin{array}{c}\text { Standardized } \\
\text { Coefficients }\end{array}}{\text { Beta }}$} & \multirow[b]{2}{*}{$\mathrm{t}$} & \multirow[b]{2}{*}{ Sig. } \\
\hline & & $\mathrm{B}$ & Std. Error & & & \\
\hline 1 & (Constant) & .642 & .257 & & 2.496 & .014 \\
\hline & Kemampuan Individu & .221 & .071 & .199 & 3.095 & .003 \\
\hline & Lingkungan Kerja & .308 & .065 & .376 & 4.743 & .000 \\
\hline & Kepuasan Kerja & .328 & .063 & .407 & 5.231 & .000 \\
\hline
\end{tabular}

a. Dependent Variable: Semangat Kerja

\section{Sumber: Hasil Olah Data SPSS, 2020}

Berdasarkan tabel, maka dapat dinotasikan persamaan dari jalur kedua yaitu:

$$
\mathrm{Y}_{2}=0,199 \mathrm{X}_{1}+0,376 \mathrm{X}_{2}+0,407 \mathrm{X}_{3}+\mathrm{e}_{2}
$$

1. Nilai koefisien jalur kemampuan individu $\left(\mathrm{X}_{1}\right)$ terhadap semangat kerja sebesar 0,199.Artinya apabila kemampuan individu $\left(\mathrm{X}_{1}\right)$ naik 1 (satu) satuan dan variabel lainnya tetap, maka semangat kerja pegawai akan meningkat sebesar 0,199. Adapun nilai signifikansi sebesar 0,003 yang berarti kemampuan individu berpengaruh signifikan terhadap semangat kerja pegawai karena nilai sig. $<0,05$.

2. Nilai koefisien jalur kemampuan individu $\left(\mathrm{X}_{2}\right)$ terhadap kepuasan kerja sebesar 0,376.Artinya apabila lingkungan kerja $\left(\mathrm{X}_{2}\right)$ naik 1 (satu) satuan dan variabel lainnya tetap, maka semangat kerja pegawai akan meningkat sebesar 0,376. Adapun 
nilai signifikansi sebesar 0,000 yang berarti lingkungan kerja berpengaruh signifikan terhadap semangat kerja pegawai karena nilai sig. $<0,05$.

3. Nilai koefisien jalur kepuasan kerja (Y1)terhadap semangat kerja sebesar 0,407.Artinya apabila kepuasan kerja (Y1) naik 1 (satu) satuan dan variabel lainnya tetap, maka semangat kerja pegawai akan meningkat sebesar 0,407 satuan. Adapun nilai signifikansi sebesar 0,000 yang berarti kepuasan kerja berpengaruh signifikan terhadap semangat kerja pegawai karena nilai sig. $<0,05$.

\section{Hasil Uji Koefisien Determinasi $\left(\mathbf{R}^{2}\right)$}

Tabel 5.19

Hasil Uji Koefisien Determinasi

\begin{tabular}{|c|c|c|}
\hline Keterangan & R Square & Adjusted R Square \\
\hline Model Jalur 1 & 0,521 & 0,511 \\
\hline Model Jalur 2 & 0,719 & 0,710 \\
\hline
\end{tabular}

\section{Sumber: Hasil Olah Data SPSS, 2020}

Berdasarkan tabel 5.19 yang merupakan hasil uji koefisien determinasi, maka dapat dihitung nilai $\mathrm{R}^{2}$ total dengan cara:

1. Menghitung e1 pada persamaan struktur 1 dengan cara :

$\left(1-R^{2}\right)^{2}=(1-0,511)^{2}=0,239$

2. Menghitung e2 pada persamaan struktur 2 dengan cara :

$$
\left(1-R^{2}\right)^{2}=(1-0,710)^{2}=0,084
$$

3. Total $\mathrm{R}^{2}=1-(\mathrm{e} 1 \mathrm{x} \mathrm{e} 2)=1-(0,239 \times 0,084)=1-0,020=0,980$

Kesimpulan untuk total $\mathrm{R}^{2}$ pada model yang digunakan adalah 0,980 atau $98,0 \%$. Artinya bahwa model dengan persamaan ini, variabel independen (kemampuan individu, lingkungan kerja, dan kepuasan kerja) mampu menjelaskan variabel dependen (semangat kerja pegawai) sebesar 98,0\% sisanya sebesar 2,0\% dijelaskan oleh variabel lain.

\section{Hasil Uji Hipotesis}

Tabel 5.20

Uji Hipotesis

\begin{tabular}{|c|c|c|c|c|}
\hline Keterangan & $\begin{array}{l}\text { Pengaruh } \\
\text { Langsung } \\
\text { (Standardized } \\
\text { Coefficcient) }\end{array}$ & Sig. & $\begin{array}{c}\text { Pengaruh } \\
\text { Tidak Langsung }\end{array}$ & Ket. \\
\hline $\begin{array}{l}\text { Persamaan Jalur } 1 \\
\text { Kemampuan individu } \rightarrow \text { Kepuasan Kerja } \\
\text { Lingkungan kerja } \rightarrow \text { Kepuasan Kerja }\end{array}$ & $\begin{array}{l}0,170 \\
0,619\end{array}$ & $\begin{array}{l}0,040 \\
0,000\end{array}$ & - & $\begin{array}{l}\text { H1 Diterima } \\
\text { H2 Diterima }\end{array}$ \\
\hline $\begin{array}{l}\text { Persamaan Jalur } 2 \\
\text { Kemampuan individu } \rightarrow \text { Semangat kerja } \\
\text { Lingkungan kerja } \rightarrow \text { Semangat kerja } \\
\text { Kemampuan Kerja } \rightarrow \text { Semangat kerja }\end{array}$ & $\begin{array}{l}0,199 \\
0,376 \\
0,407\end{array}$ & $\begin{array}{l}0,003 \\
0,000 \\
0,000\end{array}$ & $\begin{array}{l}- \\
- \\
-\end{array}$ & $\begin{array}{l}\text { H3 Diterima } \\
\text { H4 Diterima } \\
\text { H5 Diterima }\end{array}$ \\
\hline $\begin{array}{l}\text { Kemampuan individu } \\
\rightarrow \text { Kepuasan Kerja } \rightarrow \text { Semangat kerja }\end{array}$ & - & 0,053 & $\begin{array}{c}(0,170 \times 0,407)= \\
0,069\end{array}$ & H6 Ditolak \\
\hline $\begin{array}{l}\text { Lingkungan kerja } \rightarrow \text { Kemampuan Kerja } \\
\rightarrow \text { Semangat kerja }\end{array}$ & - & 0,000 & $\begin{array}{c}(0,619 \times 0,407)= \\
0,251\end{array}$ & H7 Diterima \\
\hline
\end{tabular}

Sumber: Hasil Olah Data SPSS, 2020

Hasil uji hipotesis pada Tabel untuk menggambarkan pengaruh langsung dan pengaruh tidak langsung, maka dapat disusun struktur sebagai berikut: 


\section{AkMen}

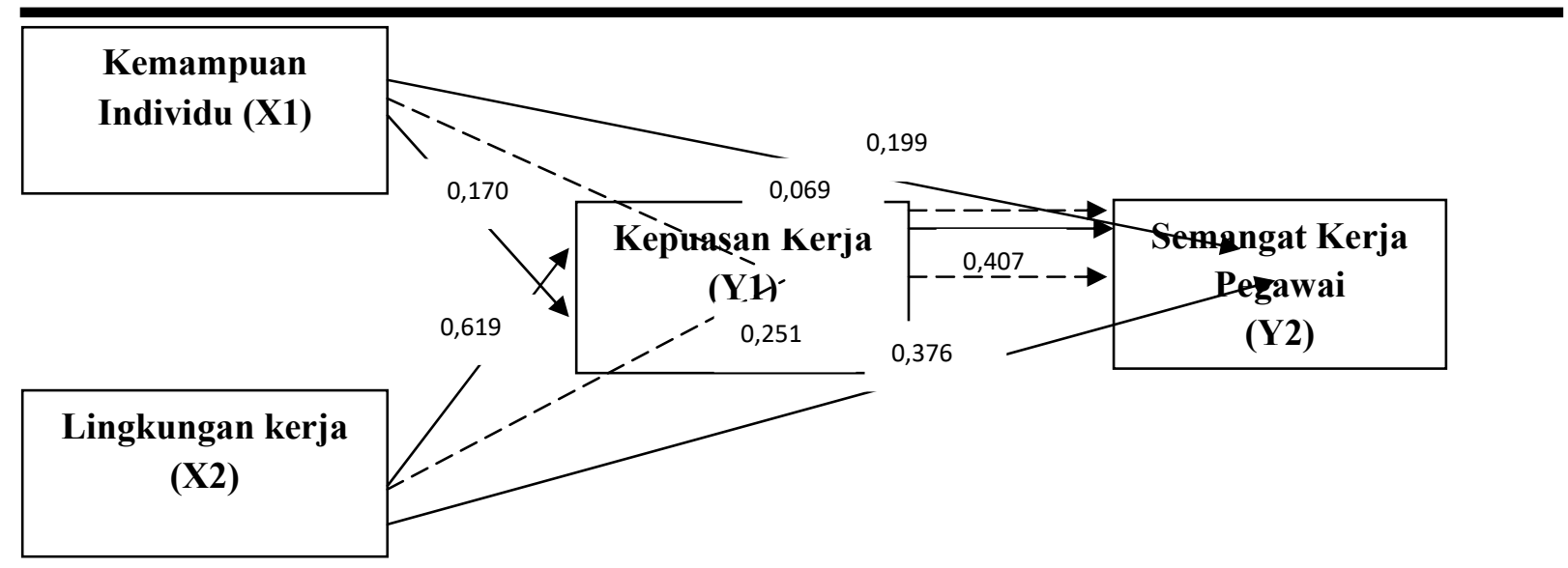

\section{Pengaruh Kemampuan Individu terhadap Kepuasan kerja}

Berdasarkan hasil uji hipotesis pada pengaruh langsung antara kemampuan individu terhadap kepuasan kerja, diperoleh nilai koefisien sebesar 0,170 dengan signifikansi 0,040 . Dikarenakan nilai koefisien bernilai positif dan mempunyai nilai signifikansi $0,040<0,05$, artinya bahwa Kemampuan individu berpengaruh positif dan signifikan terhadap kepuasan kerja pegawai Bawaslu Kabupaten Barru.

\section{Pengaruh Lingkungan kerja terhadap Kepuasan kerja}

Berdasarkan hasil uji hipotesis pada pengaruh langsung antara lingkungan kerja terhadap kepuasan kerja, diperoleh nilai koefisien sebesar 0,619 dengan signifikansi 0,000 . Dikarenakan nilai koefisien bernilai positif dan mempunyai nilai signifikansi $0,000<0,05$, artinya bahwa lingkungan kerja berpengaruh positif dan signifikan terhadap kepuasan kerja pegawai Bawaslu Kabupaten Barru.

\section{Pengaruh Kemampuan Individu terhadap Semangat Kerja pegawai}

Berdasarkan hasil uji hipotesis pada pengaruh langsung antara kemampuan individu terhadap semangat kerja pegawai, diperoleh nilai koefisien sebesar 0,199 dengan signifikansi 0,003. Dikarenakan nilai koefisien bernilai positif dan mempunyai nilai signifikansi $0,003<0,05$, artinya bahwa Kemampuan individuberpengaruh positif dan signifikan terhadap semangat kerja pegawai Bawaslu Kabupaten Barru.

\section{Pengaruh Lingkungan kerja terhadap Semangat kerja pegawai Pegawai}

Berdasarkan hasil uji hipotesis pada pengaruh langsung antara lingkungan kerja terhadap semangat kerja pegawai, diperoleh nilai koefisien sebesar 0,376 dengan signifikansi 0,000 . Dikarenakan nilai koefisien bernilai positif dan mempunyai nilai signifikansi $0,000<0,05$, artinya bahwa lingkungan kerja berpengaruh positif dan signifikan terhadap semangat kerja pegawai Bawaslu Kabupaten Barru.

\section{Pengaruh Kepuasan Kerja terhadap Semangat kerja pegawai}

Berdasarkan hasil uji hipotesis pada pengaruh langsung antara kepuasan kerja terhadap semangat kerja pegawai, diperoleh nilai koefisien sebesar 0,407 dengan signifikansi 0,000 . Dikarenakan nilai koefisien bernilai positif dan mempunyai nilai signifikansi $0,000<0,05$, artinya bahwa kepuasan kerja berpengaruh positif dan signifikan terhadap semangat kerja pegawai Bawaslu Kabupaten Barru.

\section{Pengaruh Kemampuan Individu terhadap Semangat Kerja melalui Kepuasan Kerja Pegawai}

Berdasarkan hasil uji hipotesis pada pengaruh tidak langsung antara kemampuan individu terhadap semangat kerja melalui kepuasan kerja pegawai, diperolehnilai koefisien tidak langsung sebesar 0,069. Berdasarkan hasil uji sobel test, menunjukkan nilai signifikan ( $p$-value) sebesar 0,053. Dikarenakan nilai koefisien bernilai positif dan 
mempunyai nilai signifikansi $0,053>0,05$, artinya bahwa kemampuan kerja berpengaruh positif namun tidak signifikan terhadap semangat kerja melalui kepuasan kerja pegawai Bawaslu Kabupaten Barru.

\section{Pengaruh Lingkungan Kerja terhadap Semangat Kerja melalui Kepuasan Kerja Pegawai}

Berdasarkan hasil uji hipotesis pada pengaruh tidak langsung antara lingkungan kerja terhadap semangat kerja melalui kepuasan kerja pegawai, diperoleh nilai koefisien tidak langsung sebesar 0,251. Berdasarkan hasil uji sobel test, menunjukkan nilai signifikan ( $p$-value) sebesar 0,000. Dikarenakan nilai koefisien bernilai positif dan mempunyai nilai signifikansi $0,000<0,05$, artinya bahwa kemampuan kerja berpengaruh positif dan signifikan terhadap semangat kerja melalui kepuasan kerja pegawai Bawaslu Kabupaten Barru.

Implikasi dari temuan ini bahwasanya, kepuasan kerja dapat memediasi pengaruh lingkungan kerja terhadap peningkatan semangat kerja pegawai di Bawaslu Kabupaten Barru. Dalam hal ini, Bawaslu Kabupaten Barru dalam meningkatkan semangat kerja pegawai memiliki opsi yakni melalui peningkatkan kemampuan individu secara langsung, atau dapat juga secara tidak langsung melalui kepuasan kerja sehingga semangat kerja pegawai meningkat.

\section{SIMPULAN DAN SARAN Simpulan}

Berdasarkan penelitian yang telah dilakukan terhadap pegawai di Bawaslu Kabupaten Barru dalam upaya menyelidiki pengaruh kemampuan individu dan lingkungan kerja terhadap semangat kerja melalui kepuasan kerja pegawai, maka dapat diambil kesimpulan sebagai berikut : 1). Kemampuan individu berpengaruh positif dan signifikan terhadap kepuasan kerja pegawai pada kantor Bawaslu Kabupaten Barru. 2). Lingkungan kerja berpengaruh positif dan signifikan terhadap kepuasan kerja pegawai pada kantor Bawaslu Kabupaten Barru. 3). Kemampuan individu berpengaruhpositif dan signifikan terhadap semangat kerja pegawai pada kantor Bawaslu Kabupaten Barru. 4). Lingkungan kerja berpengaruh positif dan signifikan terhadap semangat kerja pegawai pada kantor Bawaslu Kabupaten Barru. 5). Kepuasan kerja berpengaruh positif dan signifikan terhadap semangat kerja pegawai pada kantor Bawaslu Kabupaten Barru. 6). Kemampuan individu berpengaruh positif namun tidak signifikan terhadap semangat melalui kepuasan kerja pegawai pada kantor Bawaslu Kabupaten Barru. 7). Lingkungan kerja berpengaruh positif dan signifikan terhadap semangatmelalui kepuasan kerja pegawai pada kantor Bawaslu Kabupaten Barru.

\section{Saran}

Berdasarkan hasil pembahasan serta kesimpulan dalam penelitian ini, maka penulis memberikan saran sebagai berikut : 1). Disarankan agar Bawaslu Kabupaten Barru lebih memperhatikan aspek kemampuan individu pegawai, khususnya meningkatkan kemampuan bersaing pegawai dengan rekan kerjanya. Disamping itu dalam aspek lingkungan kerja juga perlu diperhatikan khususnya kemampuan pimpinan dalam menjalin hubungan yang baik dengan bawahannya. Hal ini sangat dibutuhkan untuk dapat meningkatkan semangat kerja pegawai agar semakin meningkat. 2). Kepuasan kerja cukup berperan penting dalam memediasi pengaruh kemampuan individu dan lingkungan kerja terhadap semangat kerja pegawai. Olehnya itu, perlunya 
meningkatkan kepuasan kerja pegawai karena dapat menjadi alternatif jika terjadi permasalahan dalam peningkatan kemampuan individu dan kondisi lingkungan kerja yang kurang kondusif. Aspek kepuasan kerja pegawai yang masih perlu ditingkatkan yakni dalam hal promosi jabatan yang ada, misalnya dengan lebih memberikan kesempatan yang sama bagi setiap pegawai di Bawaslu Kabupaten Barru.

\section{DAFTAR PUSTAKA}

Amar, A., \& Hidayah, S. (2019). Analisis Pengaruh Disiplin Kerja Dan Kemampuan Kerja Terhadap Kepuasan Kerja Dengan Iklim Organisasi Sebagai Variabel Moderasi Pada Kantor Pertanahan Kota Semarang. Dharma Ekonomi, 26(50).

Arikunto, S. 2006. Metode Penelitian Kualitatif. Jakarta: Bumi Aksara

Aruan, Q. S., \& Fakhri, M. (2015). Pengaruh Lingkungan Kerja Terhadap Kepuasan Kerja Karyawan Lapangan Departemen Grasberg. Modus, 27(2), 141-162.

As'ad, Moh, 2001. Psikologi Industri, Yogyakarta: Liberty.

Darmawan. 2013. Metode Penelitian Kuantitatif. Bandung: Remaja Rosdakarya.

Davis, Keith \& John W. Newstorm.2008.Perilaku dalam Organisasi. Jakarta: PT. Erlangga.

Echdar, S. (2017). Metode Penelitian Manajemen dan Bisnis. Bogor: Ghalia Indonesia.

Fathoni, Abdurrahman. 2006. Manajemen Sumber Daya Manusia. Jakarta. PT Rineka. Cipta.

Handoko, T Hani. 2000. Manajemen Personalia dan Sumberdaya Manusia. Edisi II, Cetakan Keempat Belas, Yogyakarta: Penerbit BPFE.

Hasibuan, M. S. P. (2014), Manajemen Sumber Daya Manusia, PT. Bumi Aksara, jakarta.

Kusumasari, B. (2014). Manajemen bencana dan kapabilitas pemerintah lokal. Yogyakarta : Penerbit Gava Media.

Luthans, Fred. 2007. Perilaku Organisasi. Alih Bahasa. Yogyakarta: Andi Offset.

Mathis, Robert L. 2006. Human Resource Management (edisi 10). Jakarta: Salemba Empat.

Nitisemito, A. S. (2009). Manajemen Personalia, Edisi Revisi. Jakarta: Ghalia Indonesia.

Nurbudiyani, I. (2016). Pengaruh Kepuasan Kerja dan Lingkungan Kerja Terhadap Semangat Kerja Pegawai Universitas Muhammadiyah Palangkaraya. Anterior Jurnal, 16(1), 7-13.

Pasaribu, P. D., \& Jonyanis. (2017). Pengaruh Lingkungan Kerja Terhadap Semangat Kerja Karyawan Pada CV. Jaya Karya Pekanbaru. JOM Fisip 4(1). 
Rahman. (2017). Pengaruh Kepuasan Kerja Terhadap Semangat Kerja Karyawan Pada PT. Bangun Nusantara Jaya Makmur (BNJM) Kabupaten Tabalong. Jurnal Pemikiran dan Penelitian Administrasi Publik dan Administrasi Bisnis. 1(1).

Rivai, V. (2010). Manajemen Sumber Daya Manusia Perusahaan: Dari Teori ke Praktik, Edisi Kedua. Jakarta: PT Raja Grafindo Persada.

Robbins, S. P., \& Judge, T. A. (2006). Perilaku organisasi. Edisi kesepuluh. Jakarta: PT Indeks Kelompok Gramedia.

Robbins, S. P, 2003. Perilaku Organisasi, Jilid 2, PT. Indeks KelompokGramedia, Jakarta

Sampurno. 2011. Manajemen strategi. Yogyakarta Gadjah Mada: UniversityPress

Saputra, R. A., Indarti, S., \& Garnasih, R. L. (2019). Pengaruh Kemampuan, Kepribadian, Dan Sikap Terhadap Semangat Kerja Dan Kinerja Karyawan PT. Prima Rintis Kota Pekanbaru. Jurnal Tepak Manajemen Bisnis, 11(2), 371.

Saydam, Gouzali. 2005. Manajemen Sumber Daya Manusia: suatu PendekatanMikro. Jakarta: Djambatan.

Schultz, D., \& Schultz, E. S. (2010). Psychology and work today (10 edition). New York: Pearson

Sedarmayanti. 2001. Sumber Daya Manusia dan Produktivitas Kerja. Bandung: Mandar Maju.

Sekartini, N. L. (2017). Pengaruh Kemampuan Kerja, Disiplin Kerja, Motivasi Kerja terhadap Kepuasan Kerja dan Kinerja Karyawan Administrasi Universitas Warmadewa. Jurnal Ekonomi \& Bisnis JAGADITHA, 3(2), 64-75.

Sigit, S. (2003). Esensi perilaku organisasi. Yogyakarta: Lukman Offset.

Sitinjak, L. N. (2018). Pengaruh Lingkungan Kerja terhadap Kepuasan Kerja Karyawan (Studi Pada Karyawan PT. Mitra Pinasthika Mustika Rent Tangerang Selatan). Jurnal Administrasi Bisnis, 60(2), 162-168.

Sugiyono. 2008. Metode Penelitian Kunatitatif Kualitatif dan R\&D. Bandung. Alfabeta.

Sulistiyono, E., Paramita, P. D., \& Hasiholan, L. B. (2016). Pengaruh Pendidikan, Kemampuan Kerja Dan Disiplin Kerja Terhadap Semangat Kerja Karyawan Harian Lepas Di PT Temprina Media Grafika Semarang. Journal of Management, 2(2).

Sunyoto, Danang. 2013. Teori, Kuesioner, dan Proses Analisis Data Perilaku Organisasional. Yogyakarta: CAPS.

Syamsuddin dan Bachtiar, T. (2018). Pengaruh Lingkungan Kerja Dan Motivasi Terhadap Semangat Kerja Divisi Produksi Karyawan pada PT. Utama Gas Multi Perkasa Cabang Serang. Sains Manajemen, 4(1). 

AkMen
Volume 17 Nomor 2 Juni 2020
Hal.218-228
e-ISSN : 2621-4377 \& p-ISSN : 1829-8524
Hbmepage: https//e-jurnal.stienobel-indonesia.acid/index.php/akmen

Thoha, Miftah. (2009). Perilaku Organisasi. Bandung: PT Raja Grafindo Persada.

Wibowo. 2007. Manajemen Kinerja. Jakarta: PT. Raja Grafindo Persada.

Widodo Sri, S. (2015). Manajemen Sumber Daya Manusia: teori perencanaan Strategi isu-isu utama dan globalisasi.

Winardi, A. (2004). Teori Perilaku Birokrasi. Jakarta: Penerbit Balai Pustaka.

Siagian. P. Sondang. 2005. Fungsi-fungsi Manajemen. Jakarta. Penerbit Bumi Aksara 